\title{
The Excellence of Yamazakura: Mountain Cherries and the Disappearing Tradition of Ukiyo-e Craft
}

\author{
Tuula Moilanen \\ School of Arts, Design and Architecture, Aalto University, Helsinki, Finland \\ tuulamoilanen.woodcuts@gmail.com
}

\begin{abstract}
Cherry blossom, sakura, is one of the visual symbols of Japan. For Japanese people it represents the beauty and fragility of life. Cherry tree belongs to the Rose family, which includes nearly 3000 different sub-species of flowering plants. Prunus serrulata, sometimes called as Oriental Cherry, is a species native to Japan, Korea and China. In Japan, cherry trees are roughly divided in yamazakura, wild mountain cherries and satozakura, cultivated cherry trees growing in residential areas. Moilanen's research concentrates on the special properties of yamazakura, and its use in manufacturing printing blocks for traditional ukiyo-e woodblock prints. The unique craft of ukiyo-e is gradually fading into history due to lack of successors. Difficulties in finding proper yamazakura wood material for making the printing blocks add to the problem. Moilanen gives an overview to the art of ukiyo-e and the present day situation in printing block manufacturing. Her article also includes an introduction of other wood qualities used in Japan for printmaking and a short report about a Finnish attempt for finding an alternative wood material to yamazakura. Research on heat-treated alder and birch was conducted in Aalto University in Helsinki 2008-2012. Finally, the current state of yamazakura in Japan is estimated, and the future prospects of ukiyo-e printmaking.
\end{abstract}

\section{Keywords}

Yamazakura - cherry tree - ukiyo-e - woodblock printmaking - Japanese traditional crafts 


\section{The Japanese People and Sakura}

Cherry blossom (or "sakura") is known worldwide as one of the visual symbols of Japan. For the Japanese people, it represents the beauty and fragility of life. The transience of the delicate flowers has inspired Japanese artists, musicians, poets, and craftsmen throughout history. Even today, when cherries blossom in the spring, people gather at scenic places and popular gardens to enjoy the beginning of the year. The tradition of "hanami" or cherry blossom-viewing dates back to the Heian-period (794-1185). It is certain that the cherry trees are rooted deeply in the core of Japanese culture (Fig. 1).

In addition to how visually appealing its short-lived flowers are, the cherry tree has also molded Japanese culture in a more tangible way. Cherry wood has been used in various wooden fittings in historical buildings as well as for interior elements, such as thresholds and pillars of tokonoma alcoves. It has also been a raw material for high-quality furniture and musical instruments. Furthermore, it can be found in some special tea utensils that are coated by thin sheets of cherry bark.

The elegant wood pattern complements the simplicity and grace of the tea ceremony, which is known for favoring natural materials. Until the later 19th century, cherry wood was also essential in the Japanese publishing world. All printed matter, ranging from religious and educational texts to picture books, advertisements, newspapers, and ukiyo-e artworks were produced from printing blocks made of cherry wood. These prints are generally referred to as "woodblock prints" or "woodcut prints," or sometimes by their Japanese name, "mokuhanga."

In the West, the most famous examples of Japanese woodblock prints have originated from the Edo-period (160o-1868). They are masterpieces of ukiyo-e, "pictures of the Floating World." The best-known ukiyo-e motifs are of famous kabuki actors, beautiful women and historical scenes and landscapes (Fig. 2). A lot of research exists on the artists who designed these prints. However, the technique of print publishing from the Edo-period was not properly understood until quite recently. Only in the 199os did the Japanese traditional woodcut method start gaining more attention in the international art circles. Nowadays contemporary printmakers all over the world are eager to learn this unique technique and to know more about the wood used in it.

While the interest in Japanese woodblock printing techniques is increasing internationally, the continuance of the old ukiyo-e print tradition is threatened by a lack of successors in Japan. Today, there are less than 70 professional craftsmen in Japan who have preserved the knowledge of ukiyo-e carving and printing (Fig. 3). Although the ukiyo-e craftsmen receive much needed 


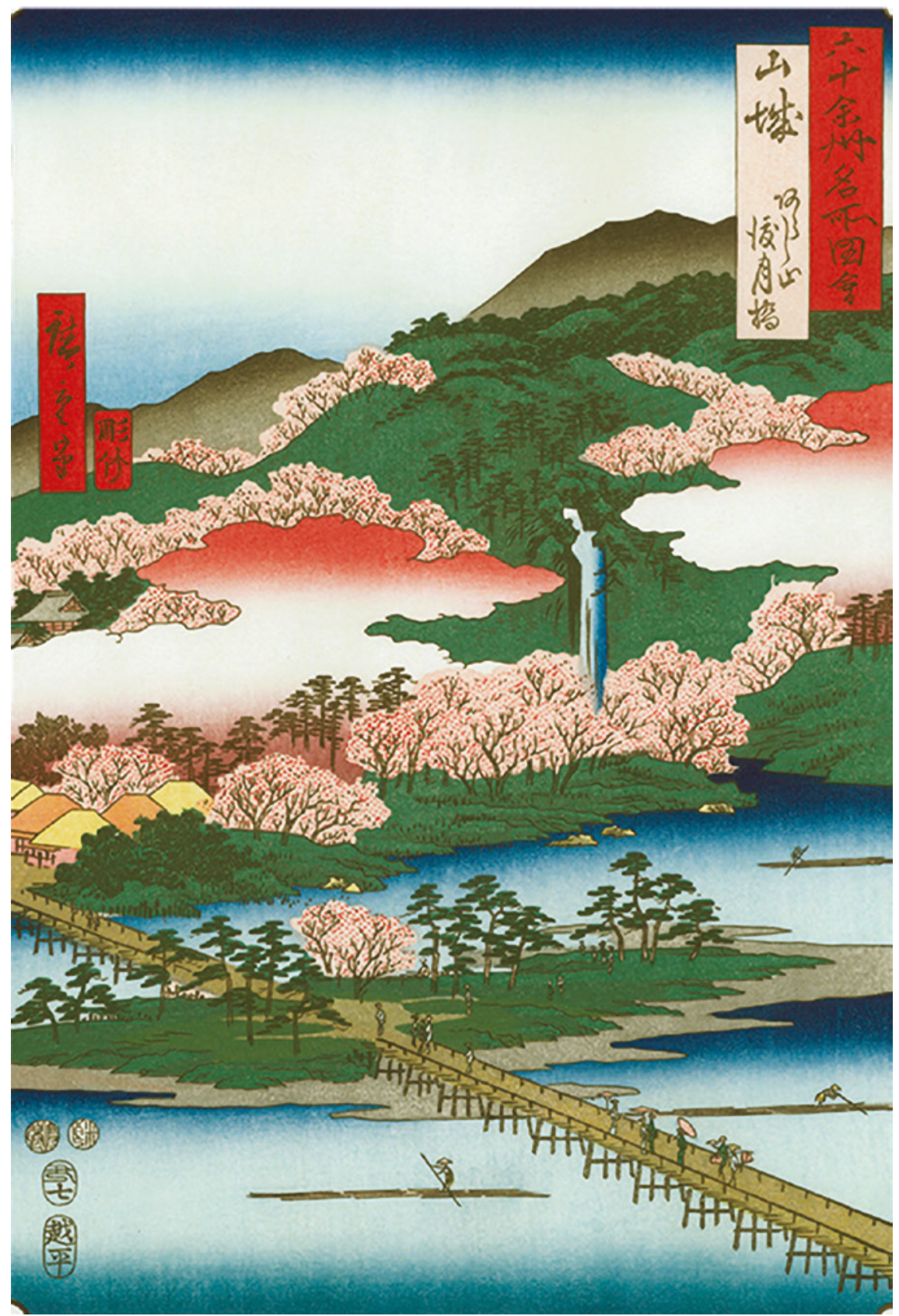

FIGURE 1 Utagawa Hiroshige (1853). A Ukiyo-e woodblock print depicting the Togetsukyo Bridge, Arashiyama Kyoto during the cherry blossom season. 

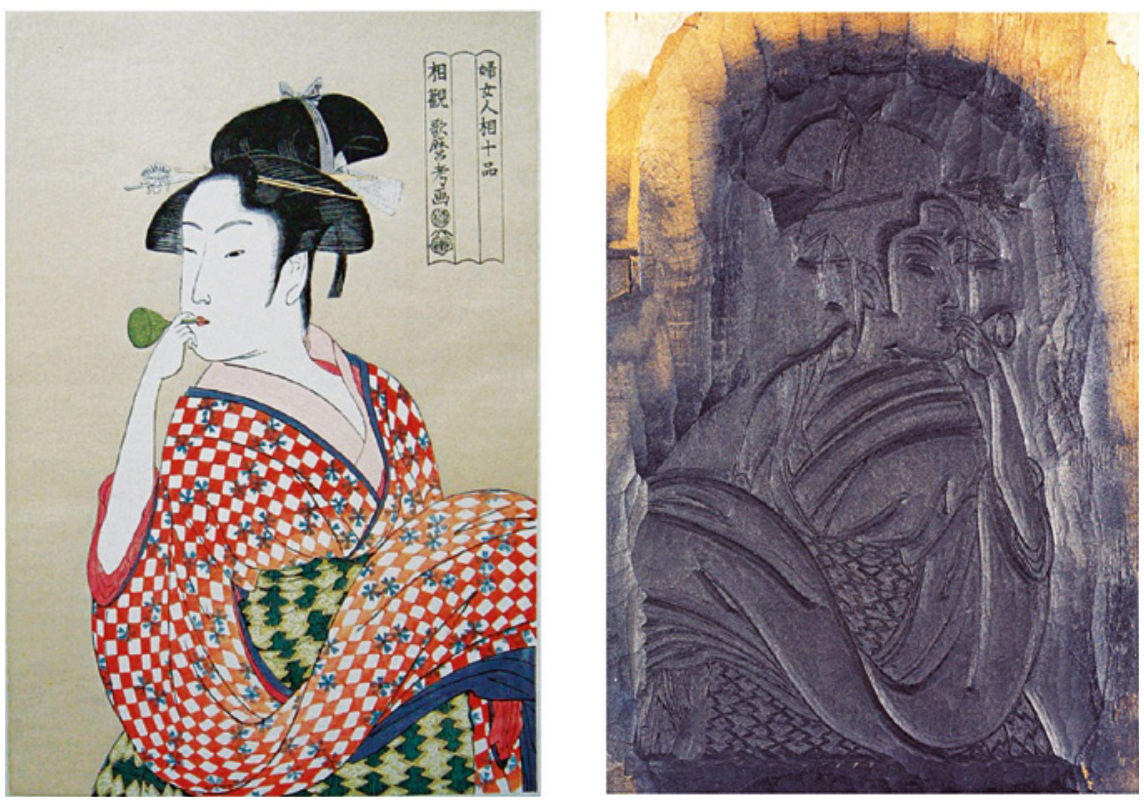

FIGURE 2 Kitagawa Utamaro (1753-1806). On the left: Woman blowing a glass pipe. Ukiyo-e woodblock print ( fukkoku). On right: Key block for Utamaro's print.

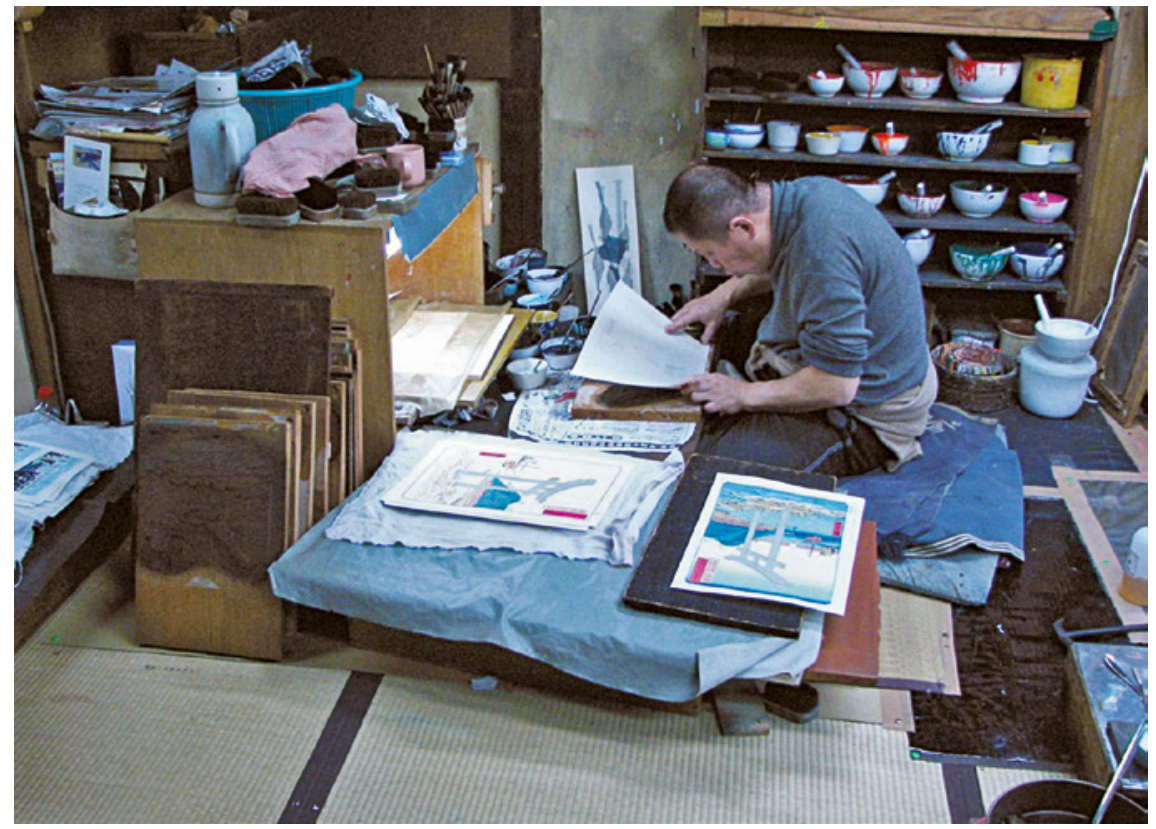

FIGURE 3 An ukiyo-e printer at work in Sato Mokuhanga Kōbō in Kyoto. 
financial support from the Japanese government for their work, the young generation of artists has no interest or patience in training themselves in this extremely demanding craft.

In the research at hand, I have focused on introducing mountain cherry and its unique wood quality used to make ukiyo-e woodblock prints. As the old tradition is rapidly disappearing, it is vitally important to the future generations to be able to access the surviving knowledge of the materials and the working methods of ukiyo-e passed down by the Old Masters.

The cherry tree belongs to the Rose family, which includes nearly 3000 different sub-species of flowering plants. Prunus serrulata, sometimes called the Hill Cherry, Oriental Cherry, or East Asian Cherry, is a species of cherry native to Japan, Korea, and China.

In Japan, cherry trees are roughly divided in two main types. In one category are the "yamazakura" or wild mountain cherries, also known as "honsakura." They include four types of cherries: "yamazakura," (prunus donarium); "ōyamazakura," (prunus speziosa); "ōshimazakura," (prunus sargentii); and "kazumizakura," (prunus verecunda). The other main category is called "satozakura" or village cherries, which indicates that the cherry species grow near residential areas and in gardens and parks. The "satozakura" category is large, comprising over 300 different types of cherry. One of the most common "satozakura" is the "someiyoshino" (prunusyedoensis), which is cultivated from wild "ōshimazakura" and used for purely decorative purposes.

Cherry trees bloom only for a short period from the middle of March to the end of April. The blossom time varies among the different cherry types, starting with "someiyoshino," which produces the earliest flowers. Despite the overwhelming fragrant clouds of flowers, many satozakura trees do not produce fruits. They also tend to become hollow when they get older, which naturally diminishes the possibilities to be use as felled tree trunks. The oldest cherry trees in Japan are estimated to be over 1500 years old.

The simplest way to make a distinction among the vast variety of cherry trees is to check the height of the full-grown tree and the shape and color of its flowers. Some species are known to bear 5 single petals, some 6 or even 8. There are also those species with ${ }^{10-50}$ double-layered petals and heavy chrysanthemum-like blossoms bearing over a hundred petals. The colors of cherry flowers are known to vary across white, yellowish, greenish, and shades of light and dark pink. 
Amongst all the types of cherry wood, the mountain cherry, especially the oshimazakura, has been proven to be the best block material for producing Japanese traditional ukiyo-e prints.

Old records (kept in 1912) on the professional block makers' daily routine reveal that boards coming from Izu and Nikkō were the most popular material in late Edo-Meiji period. Towards the end of the 19th century, cherry lumber production extended all the way to the Tohoku region (northeast Japan). In spring, mountain cherry flowers and foliage appear simultaneously, but someiyoshino and other cultured decorative trees grow leaves only after losing their flowers. Mountain cherries are identified by their pure white flowers, which bear five petals. In natural conditions, yamazakura trees enjoy a long life span. They can grow over 20 meters in height and up to one meter in circumference. Mountain cherries have straight trunks, whereupon the branches develop on a higher level than the other cherry species. This feature makes it possible to obtain long and even-quality boards from the trunk.

Yamazakura is a 'diffuse-porous' wood. This means that its pores are evenly sized, so that the conducting water is dispersed throughout the growth ring. Similar wood types are alder, basswood, birch, and aspen. There is also variation of the inner structure within the multiple cherry types. Some cherry trees form an intermediate group between 'ring-porous' and diffuse-porous wood types. In ring-porous wood, large pores form at the start of the growing season, while in latewood the pores become smaller and more uniform in size. Their vessels also become more evenly distributed when the tree grows older.

The mountain cherry heartwood is reddish brown, with paler brown sapwood around it. It has a slightly water-resistant glossy surface when polished. The wood has straight grain, tight density, and quite inconspicuous growth rings. The specific gravity of the wood is between o.62-o.68. The hard and even quality of the wood enables the carving of extremely minute details and lines on the printing block. The durability of the block surface is also a great advantage when working on large editions.

The yamazakura grows scattered on the mountains, which makes it difficult to find and harvest - and thus costly. A manual for ukiyo-e carvers and printers published in 1929 attests to the quality of the wood, quoting: "Yamazakura growing near the ocean on the Izu peninsula is the best, Nowadays it is hard to find such good wood". 
The history of Japanese woodblock printing began in the late 8th century with the inscribing of copies of Buddhist texts. The earliest known mass production was the commission of "Hyakumantō Darani," dated to the year 770. It consists of a million copies of a Buddhist sutra printed on narrow strips of paper, which were housed inside one million small wooden pagodas. About 40 ooo of these ancient pagodas have been found and preserved in museums and temple collections. However, the material of the printing blocks for Hyakumantō Darani remains a mystery. The historical records of Japanese art reveal that the Japanese learned woodblock printmaking and papermaking from China via Korea during the $7_{\text {th }}$ century. Unfortunately, there are no written records about the exact wood types used in those early stages of woodblock printmaking (Fig. 4). The first Japanese woodblocks are lost in time.

The Japanese ukiyo-e printing technique reached its zenith during the late Edo-period (1603-1868). The publishing business during this period flourished, especially in Edo (present day Tokyo) and the Kamigata region (Kyoto-Osaka). The painter, Hishikawa Moronobu, is considered to be the first genuine ukiyo-e style artist. He moved to Edo in the 166os and worked at the capital as a successful illustrator of books. At that time, Edo was undergoing massive
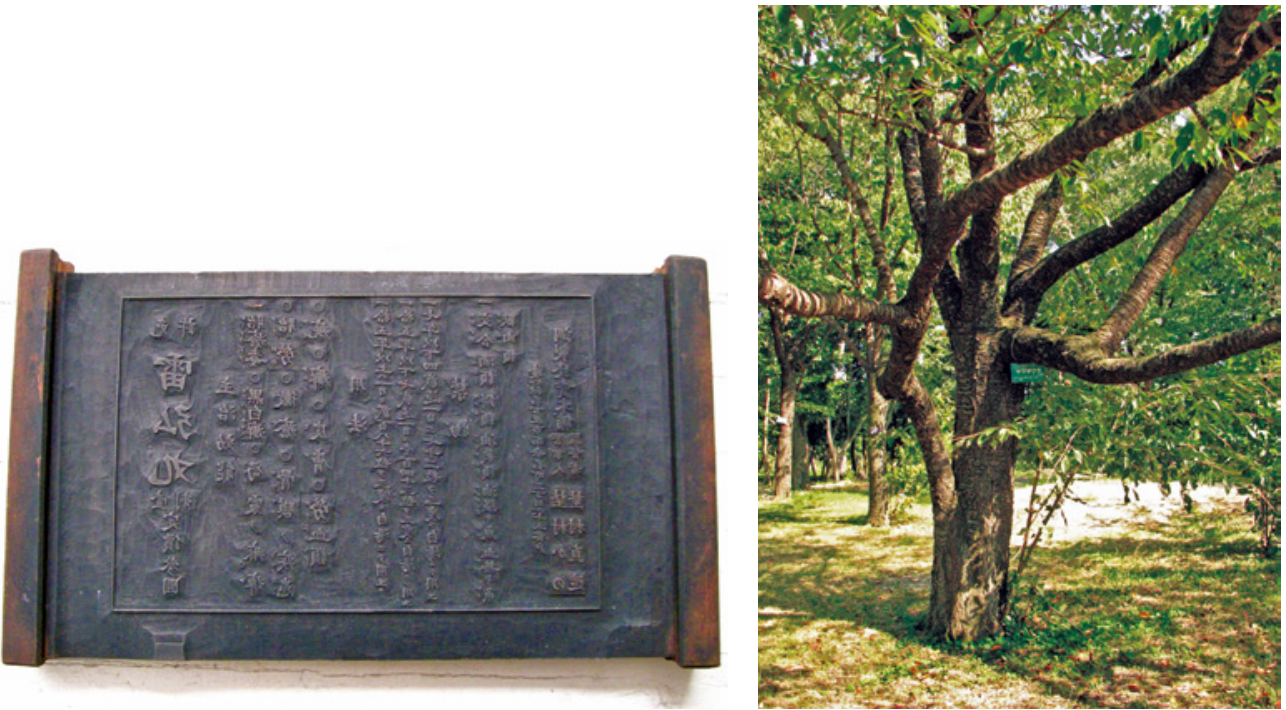

FIGURE 4 (Left) Old printing block with hashibami, narrow strips of wood attached to both ends of the block. Hashibami clamps prevented the block from warping. (Right) Yamazakura tree sample in Kyoto Botanical garden in September 2014. 
reconstruction after the powerful earthquake in 1657 . The majority of the population belonged to the male gender; carpenters, craftsmen, merchants, and members of the warrior class poured into the city, giving rise to a new cultural atmosphere. The concept of ukiyo or the "Floating World," signifying the fleeting moments of pleasure in the red-light districts of the city, was born. It depicted the contrast of the world of carnal pleasure, which followed the ardent routine and hard work of those days.

The ukiyo-e art is divided in three main genres:

(1) Original paintings on silk or on paper (nikushitsu)

(2) The wood block printed books (hanbon)

(3) The wood block printed pictures (mokuhanga)

The woodblock printed pictures became popular collectible items among the common classes. The first ukiyo-e prints were black and white portraits of famous beauties as well as kabuki actors. The invention of kentō, the registration method for color printing in 1765 , marks the beginning of nishiki-e (brocade picture) production, which led to the Golden Era of ukiyo-e printmaking from the late 18th to mid-19th century. By then, other motifs such as sumo wrestlers, warriors, historical events, landscapes, and local beauties in their daily work were included in print production.

Ukiyo-e prints were designed to imitate the delicate brush marks of the original paintings, which inspired the block carvers to greatly develop their carving skills. The finest example of carving can be found in the hairline of a geisha print, where 4 perfect hairs are cut in a width of one millimeter. Such fine details are possible only by using tight-grained and hard wood, such as yamazakura and tsuge. The durability of yamazakura enabled printing companies to publish very large editions of ukiyo-e pictures. The number of prints pulled from one printing block can reach up to 20oo. Naturally the images of the first 1000 prints had sharper lines than the very last. This must have happened because constant rubbing of the surface while printing eventually flattens the raised lines.

The carving and printing skills of professional ukiyo-e craftsmen were at their peak around the turn of the 2oth century. Unfortunately, the publishing of woodblock prints had, by then, already started to decline due to the import of Western printing machines and photographic methods. It was only after the Second World War that the importance of treasuring the old methods in art and craft came into clearer focus.

The only way to preserve the ancient carving and printing skills, unchanged by technology and cultural interest, is by fukkoku production. In fukkoku, the image of an ukiyo-e print is carved again on a yamazakura block and then printed with natural pigments on Japanese washi paper. Re-carved blocks may 
produce small differences in the image when compared to the first edition blocks. These tiny telltale signs help in dating the prints and sometimes even reveal the location of their publishing. Re-carving and reprinting of bestselling ukiyo-e items had already taken place by the end of the Edo-period.

Today's fukkoku production happens under the conduct of Ukiyo-e Mokuhanga Chōshō Gijutsu Hozon Kyōkai, (the Association for the Preservation of Ukiyo-e and Mokuhanga Carving and Printing Skills), which was founded in 1977.

The Japanese government acknowledged the association in 1978 by nominating it as an official preserver of important, intangible cultural heritage. Most members of this association have already reached a venerable old age but they continue their work in contemporary Tokyo and Kyoto.

We can learn many interesting details about the Edo-period publishing world by examining the old printing blocks. Old blocks with ireki correction for a new publishing date indicates that the book (or picture) had been highly popular and sold hundreds of volumes. If the publisher's name is corrected with ireki, it proves that the ownership of the blocks has changed, and the new publisher had access to a bestseller of the time in his hands.

\section{5}

\section{Method}

Woodcut is a form of relief printing. The drawing is transferred on to a wooden block, with the white regions cut out by using knives and gouges. The raised image is inked, and a printing paper is placed over the block. The image is rubbed on the paper with a special rubbing tool or baren (Fig. 5) and in the case of oil-based inks, sometimes with a printing press. When man-made colors are used, separate wood blocks are required for each color (Fig. 6).

Japanese woodblock printmaking is a water-based and non-toxic method. All of its materials can be recycled. Many types of wood can be used in making woodcuts, but for ukiyo-e printmaking only mountain cherry or the yamazakura is good enough for satisfying printing results. The other materials used in the process, such as the paper and pigments are carefully chosen for ukiyo-e production. Only the best quality Japanese papers made from kōzo fiber and pure pigments mixed with animal glue can be used. The tools used in ukiyo-e carving and printing are an integral part of the old tradition.

It is very demanding to carve and print ukiyo-e. The carver has usually been more esteemed than the printer. An old saying goes: "Hori jünen, suri shichinen." This can be translated to: "It takes ten years to become a master carver, seven to become a master printer." 


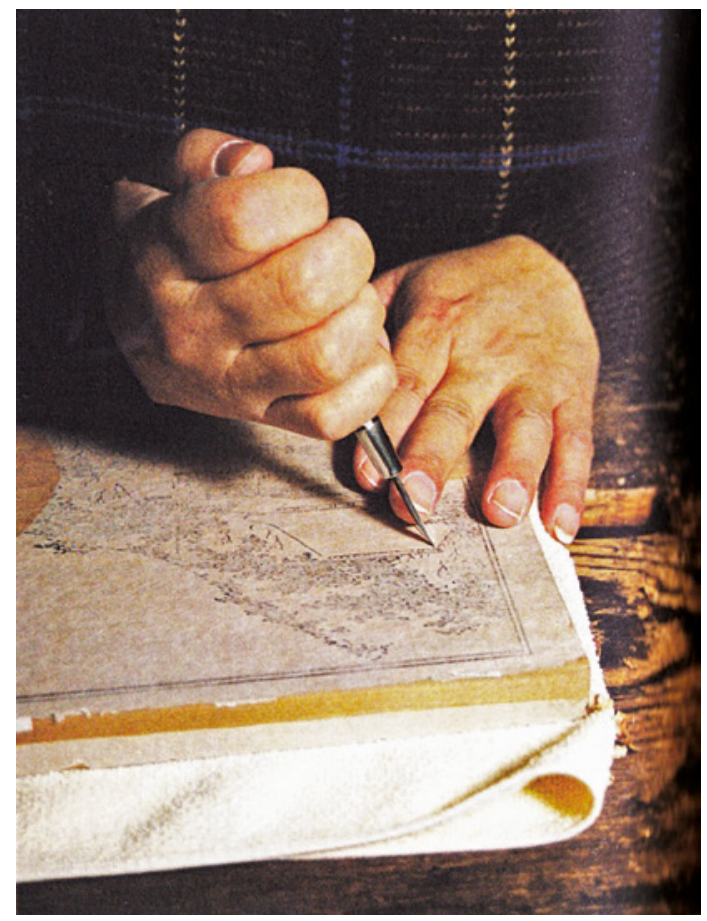

FIGURE 5 A ukiyo-e carver at work. A line drawing made on thin Japanese paper is pasted on the block. The cutting is done through the paper by tracing the brush marks.

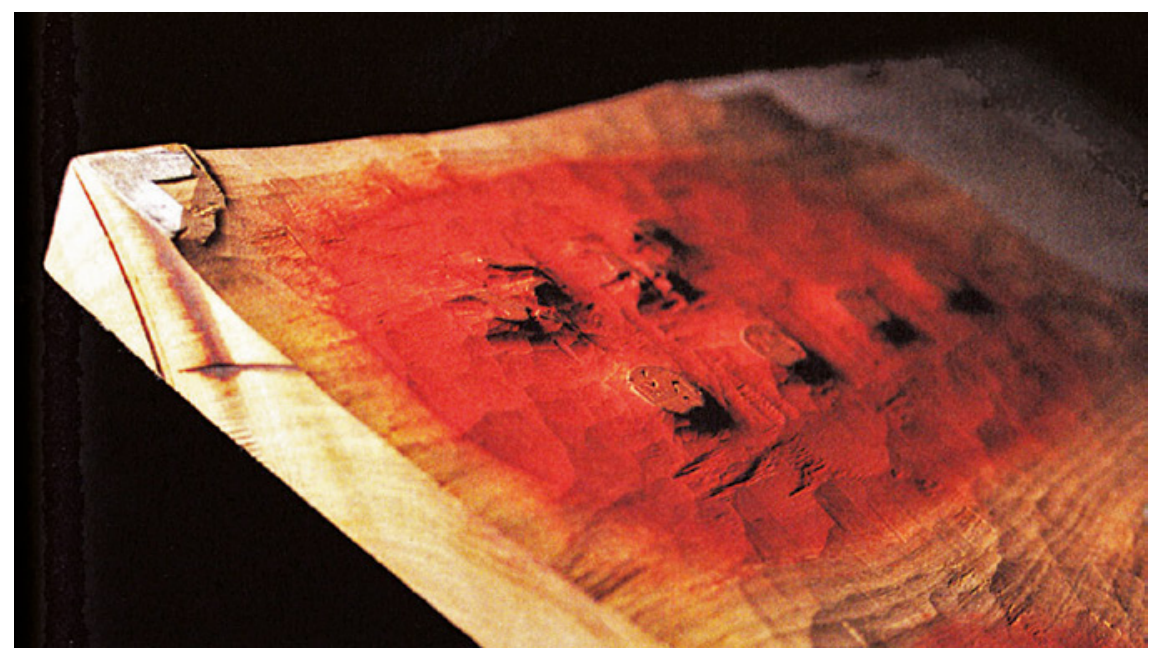

FIGURE 6 A ukiyo-e color block. Paper registration mark, kento is cut on the corner and on the long side of the block. 
Although the training period for both is much shorter in present-day Japan, dedication to work is still highly appreciated in all Japanese arts and crafts.

\section{$6 \quad$ Work of a Professional Block Maker}

The very last traditional-style block-making master was Seizo Aoyama in Kyoto. He passed away in the year 2000 without any apprentices. Aoyama left behind a large stock of well-seasoned cherry boards, about 50 years old, which were then purchased by Shigeru Matsumura in Tokyo. Today, Matsumura is the only living professional manufacturer who continues making cherry blocks and cherry plywood for woodcut printmakers. Unfortunately, the common lumberyards of today no longer have cherry tree logs in their stock, thus Matsumura is facing increasing difficulties in finding fresh yamazakura wood for further processing. Shigeru Matsumura inherited his lumberyard in 1991 from his father, who had started his business in 1954 under the company name Matsumura Zaimokuya. With the change in ownership, the name of the firm changed to the present Woodlike-Matsumura.

Shigeru Matsumura, who graduated from Tama Art University in Tokyo, highly appreciated woodcut techniques and woodcut artists. After taking over his father's company he soon began developing his lumberyard towards a special art supply shop for woodblock printmakers. Today Matsumura deals not only with orders from Japanese artists and craftsmen but has also expanded his sales internationally.

\section{$7 \quad$ Making Yamazakura Printing Blocks}

Preparing the cherry wood for Edo-style printmaking blocks takes much time and attention. The ukiyo-e craftsmen are very precise about the surface structure and the direction of the annual rings when they are choosing their wood materials.

After cutting down the tree, the trunk is sliced into $7 \mathrm{~cm}$ thick boards, which are placed to dry in open air under a covered sheet for several years (customarily for 10 years). The boards are piled up so that the air can pass freely between them. Weathering the boards outside in changing drying conditions (from rain to sun), gives the best result. Without proper ageing and slow drying, the wood warps strongly, obstructing the block preparation.

The well-aged boards are then sliced in half with a thickness of $35 \mathrm{~mm}$. The surface of the half boards is mechanically dressed. After that, the boards are 
piled once again in open air for further drying. When warping has completely stopped, the boards go through a repeated planing and drying treatment until they are absolutely straight and flawless (Figs 7 and 8).

Although nowadays, the surface of wood is polished mechanically with water and abrasive paper, hand planing is preferred as a finishing touch. Cutting the wood grain with a sharp plane gives a finer surface to the block in comparison to abrasive paper, which tends to leave some minute particles between the wood fibers. The thickness of the final printing block is between 21-27 mm (average 23-24 mm). This makes it possible to use both sides of the block for carving without the block warping too much.

The maximum size of the printing blocks for sale is determined by the size of the yamazakura tree trunks in production. Traditionally, the average size of sliced boards has been $40-50 \mathrm{~cm}$ in width and $150-180 \mathrm{~cm}$ in length (Fig. 9).

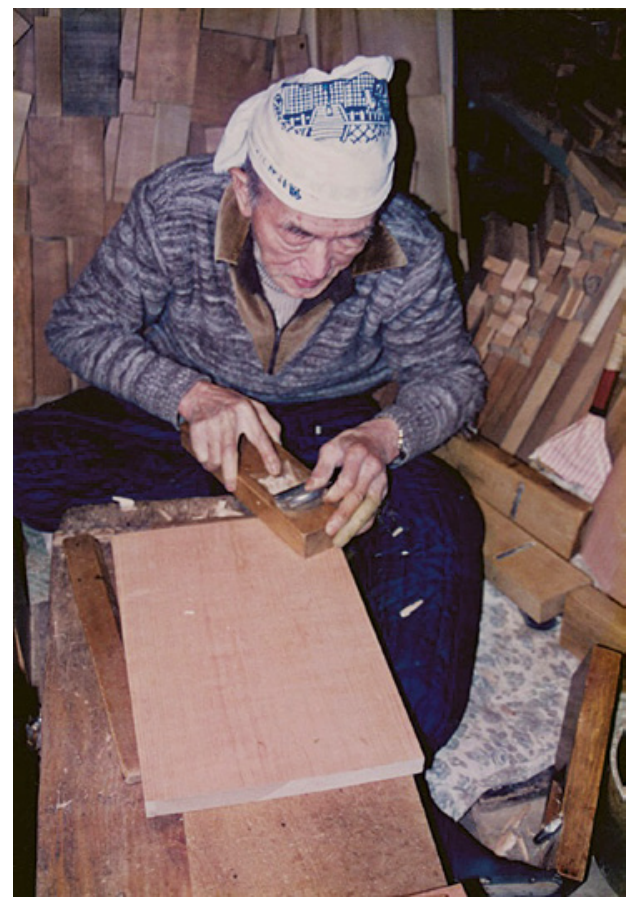

FIGURE 7 The traditional block maker Seizo Aoyama hand planing in his workshop in Kyoto in 1998. Planing has to be done evenly in all directions. The opposing direction of the wood grain gives some resistance, so the last working stage goes along the grain.

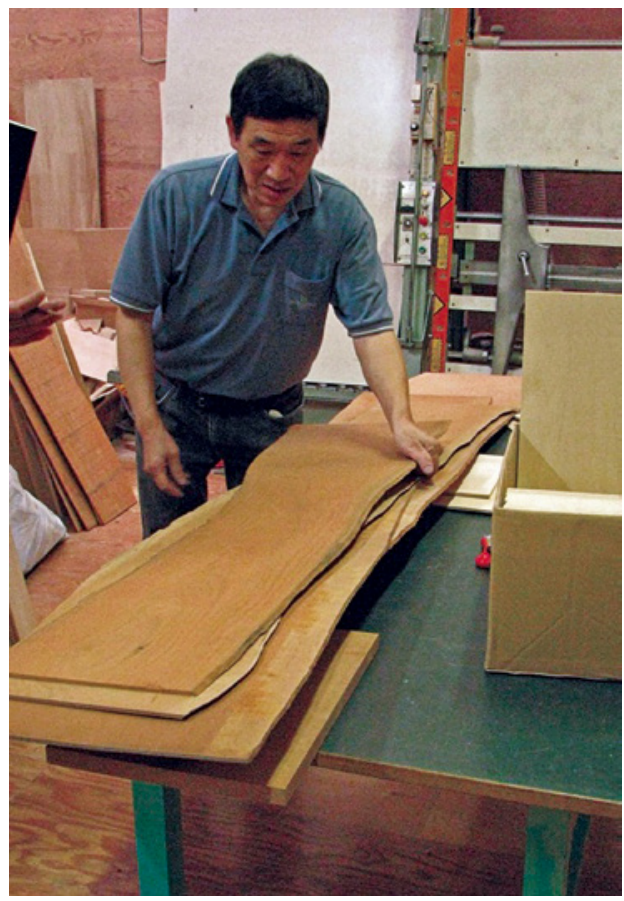

FIGURE 8 Contemporary block maker Shigeru Matsumura with sheets of cherry wood on the table in his workshop in Tokyo in 2014. 


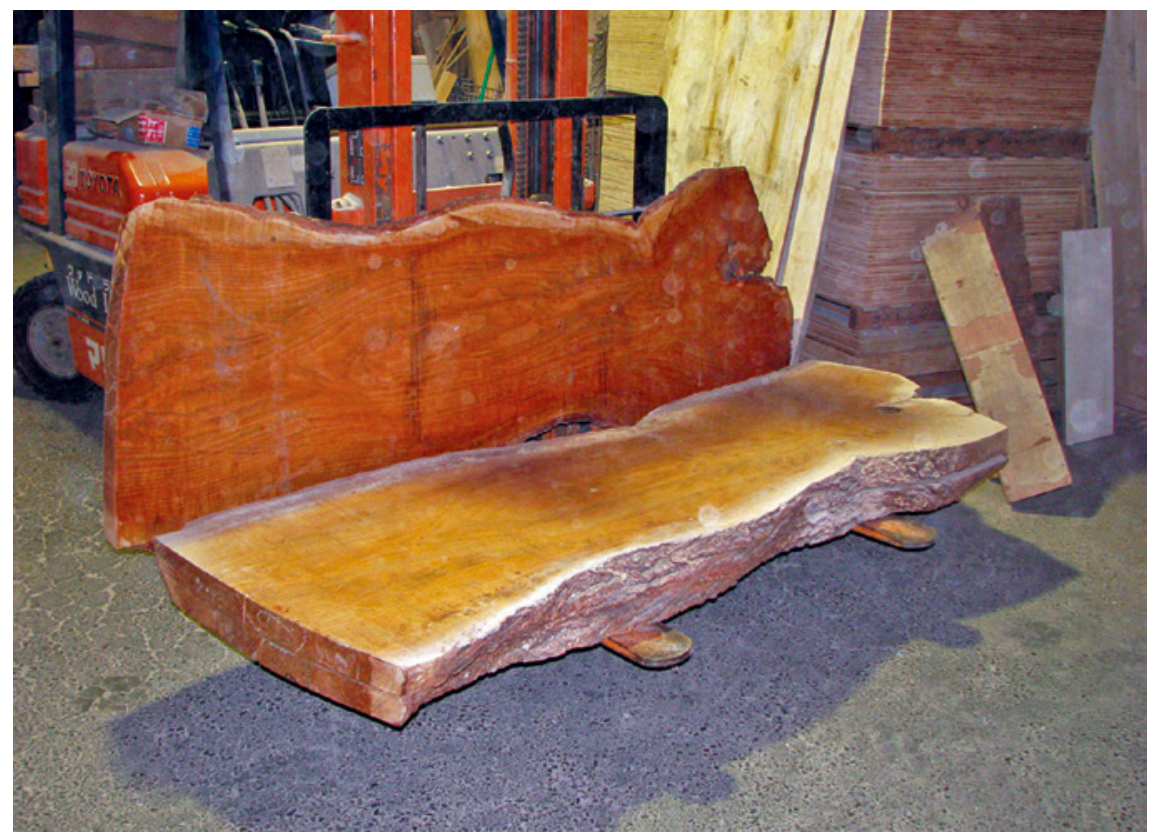

FIGURE 9 Cherry tree trunks in Matsumura's workshop. The boards are coated with a layer of glue to prevent surface scratching during handling. The protective glue is dressed away after the boards have been stored for $3-5$ years and then the process of block making begins.

Larger blocks cannot be constructed by gluing together two or more separate boards because the joint would eventually crack from constant use of water during the printing process.

Also, the bigger the printing block becomes, the more it is exposed to the danger of warping. The ukiyo-e craftsmen would not accept even a smaller constructed block, because the joints would evidently show disturbingly in the final print. However, text-blocks have formerly been made by joining two narrow boards together and by attaching supporting wood strips (hashibami) on both sides. Figure 4 shows the wood strips on the left and right side of the block.

In the Edo era, the printing blocks were made to match various printing papers, which came in standard sizes. These paper standards have not changed since the Edo period, although the number of handmade paper workshops has dropped radically. The historical oban size (ca. $39.4 \times 27.3 \mathrm{~cm}$ ), which was in wide use during the Golden Age of ukiyo-e, even today is the most used block size. In Matsumura's woodshop, the blocks can also be tailored according to 

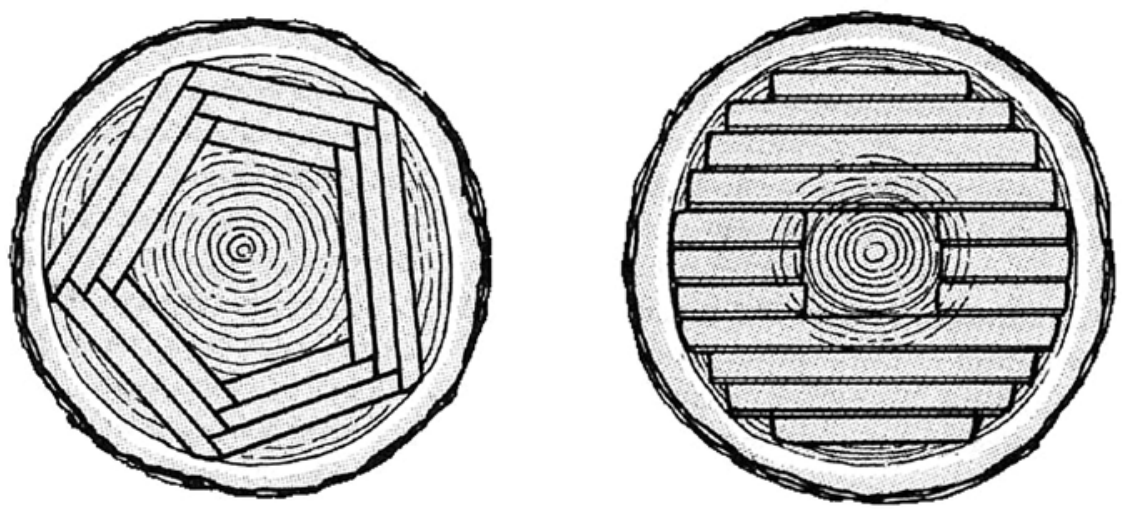

FIGURE 10 (Left) Using the older method of cutting the blocks out from the cherry trunk. (Right) More economical current method. In this method, blocks tend to warp more easily than when using the traditional method.

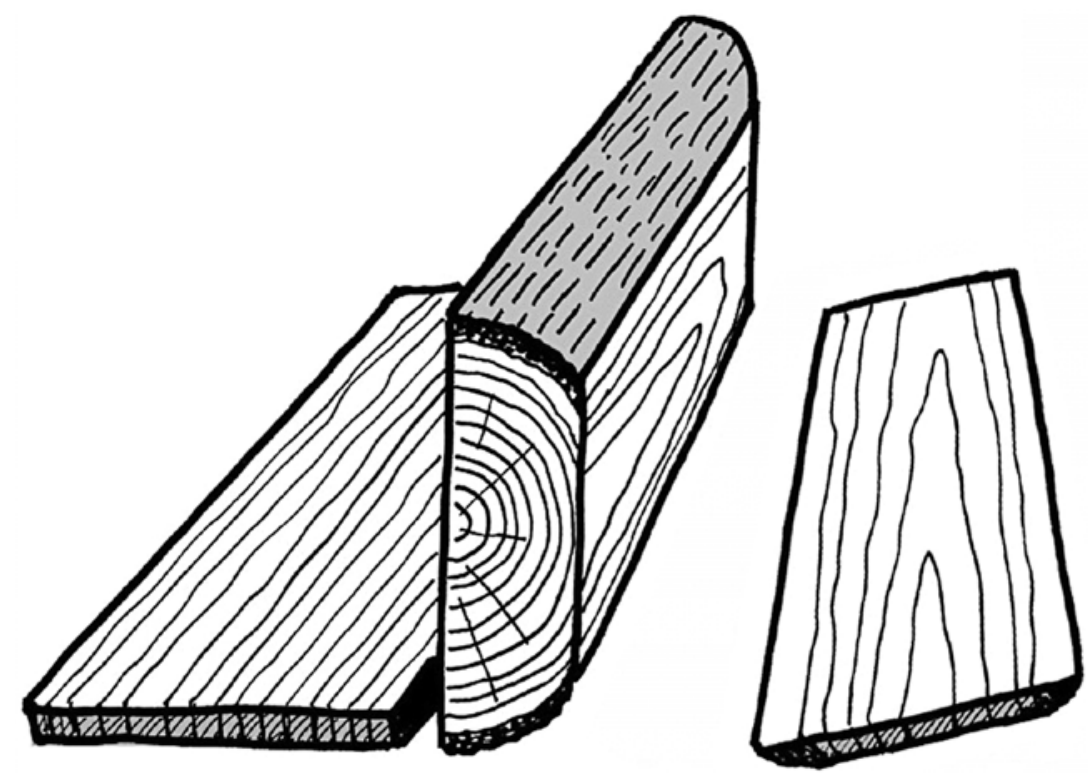

FIGURE 11 Cutting the trunk. Board cut close to the core (left) is called masame.

Masame-board has evenly dispersed straight grain, and it is considered the best quality for ukiyo-e printmaking. It is costly to make because much of its wood material is wasted. (Right) is itame board, which is cut closer to the bark. Itame has flat grain and the annual rings are not consistently spaced. 


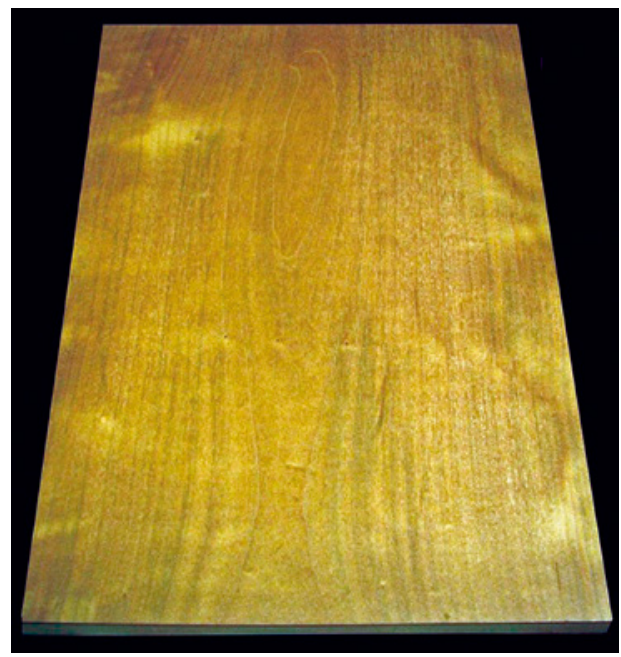

FIGURE 12 (Left) Yamazakura board for ukiyo-e printmaking. (Right) Ireki: A piece of tsuge wood, which is inserted in a yamazakura-printing block.

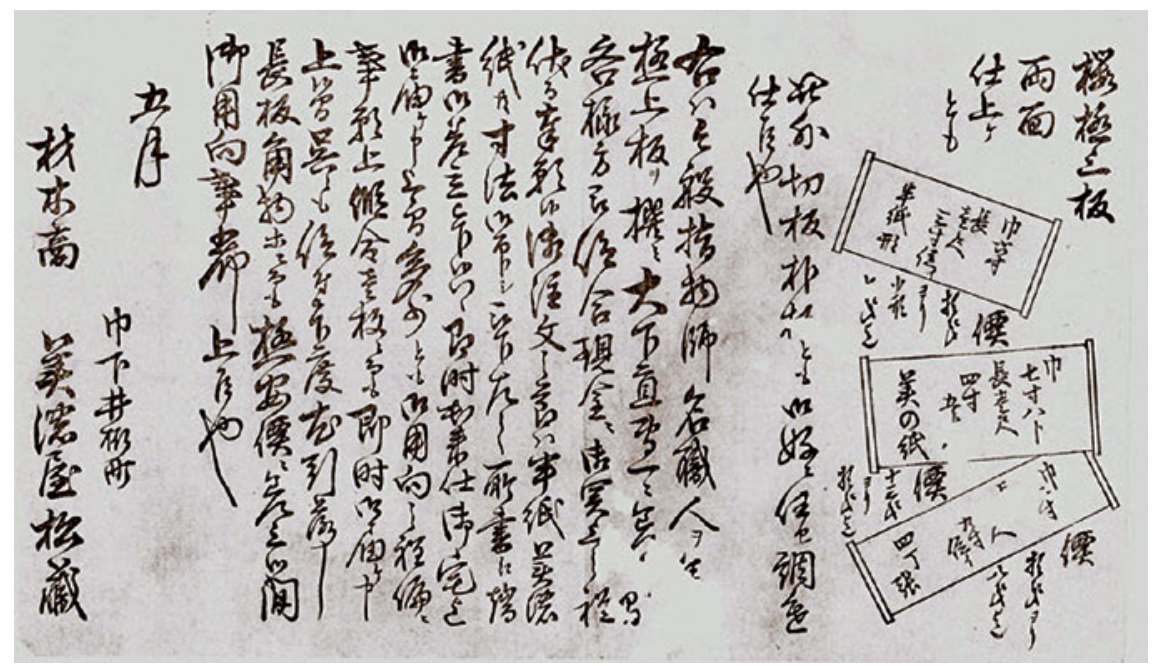

FIGURE 13 Sakura Gokujō Ita, “The Very Best Sakura Blocks”. An advertisement of block maker Matsuzō Minoya in Habashita Sugimachi. Woodblock print from the Meiji

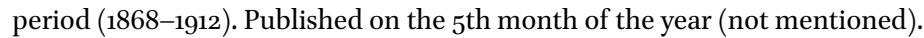
Sales items are shown on the right as simplified line drawings. The blocks are depicted with hashibami, the supporting side strips. PICTURE FROM THE SUMIO YAMAZAKI COLLECTION 
the client's specific wishes. The smallest current yamazakura blocks in the market are made for printing postcards.

The difficulty in finding proper mountain cherry wood inspired the invention of yamazakura plywood. It has already replaced full-wood blocks in most mokuhanga workshops. Cherry plywood for ukiyo-e print production is made by gluing $4 \mathrm{~mm}$ thick sheets of yamazakura on both sides of veneer made of "shina" wood (Tilia japonica). For contemporary printmaking, a yamazakura sheet, about 1-2 mm thick is sufficient. The freshly glued wood surfaces are mechanically pressed by 40 ooo kilos of weight overnight or at least for five hours. The thickness of the yamazakura plywood is made to correspond to the traditional block (23-24 $\mathrm{mm})$.

Yamazakura sheets for plywood production do not always come from lumberyards. Worn out and disposed printing blocks are often used as material for the plywood outer surface. The carved image on the old block is shaved away from both sides until the untouched wood inside is revealed. This is planed further into proper thickness for plywood manufacturing. The printing blocks for recycling come mostly from contemporary artists. The historical printing blocks, especially ukiyo-e key blocks are never used in plywood production. They have great cultural value and are carefully preserved for private and public collections. Yamazakura plywood has enabled the continuance of ukiyo-e style woodblock printmaking, but it is only a temporary solution to the wood problem in the long run.

What happens when there are no more historical blocks for recycling left?

Besides mountain cherry, some other species of wood have been long used in Japan for printmaking purposes. The most common ones are 'katsura' (cercidiphyllum japonicum) and 'hō' or the Japanese magnolia (magnolia obovata). Katsura wood has a strong grain pattern and a characteristic yellowish color. $H \bar{o}$ is distinguishable by its greenish brown shade. It is considered suitable for small sized works only, because the wood tends to expand when printing with watercolors. This obstructs the registration of the colored areas in the picture. Both katsura and hō are too soft for ukiyo-e style printmaking. 
Japanese boxwood or 'tsuge' (buxus microphylla) is sometimes used along yamazakura in ukiyo-e printmaking. A piece of tsuge wood is inlaid into the sakura block and the surface is carefully leveled. This inserting method is called ireki. Tsuge is harder than sakura and thus more laborious to work with in large areas. It is mainly used in carving those parts of the picture that include extremely fine lines like the hair of a beauty. Also, it is often used when correcting detailed carving mistakes on the block. For simple corrections, cherry wood is inset to the block instead of tsuge.

Shina-veneer is the most common block material used by contemporary Japanese woodcut artists. It is also gaining increasing international popularity due to its easy workability and smooth printing result. Despite its softness, the surface of shina block is quite durable. A print edition of between 180-200 can be taken from it before the carved image wears down. A full-sized shina-veneer sheet is around $90 \times 180 \mathrm{~cm}$, allowing artistic freedom to work with quite large prints. The color of the wood is yellowish white, and its annual rings are quite invisible. Shina is a member of the Linden family and it grows on the mountain areas of Central and North Japan. The timber for shina-veneer production originates mostly from Hokkaido.

During the period 2008-2012, a Finnish research team at the Aalto University School of Arts, Design and Architecture in Helsinki investigated the qualities and characteristics of several heat-treated wood types. The aim was to find an alternative wood material for Japanese yamazakura and to create a new block material for printing with watercolor. The research was conducted under supervision of Professor Kari Laitinen in co-operation with the University of Eastern Finland in Joensuu and the Mikkeli University of Applied Science. In Japan, Kyoto-based ukiyo-e master printer Keizō Satō and professional carver-printer Shoichi Kitamura tested the treated blocks in comparison with Japanese mountain cherry blocks. Woodblock artist and doctoral candidate Tuula Moilanen worked in Japan as a project coordinator for the team, organizing the Japanese tests and translating the test results.

The research concentrated on native Finnish alder (genus alnus) and birch (genus betula) which were artificially aged by heat treatment under temperatures ranging across $120^{\circ} \mathrm{C}, 140^{\circ} \mathrm{C}$ and $160^{\circ} \mathrm{C}$. The humidity of the working area was kept at saturated high levels so that the wood would not crack in the drying process. In laboratory measurements, it was confirmed that extremely 
high temperatures could decrease the wood's ability to absorb the water-based ink and diminish the ink transfer to the prints. In general, the temperature of $120^{\circ} \mathrm{C}$ was decided to be the best temperature for ageing the wood.

Although both heat-treated Finnish alder and birch proved to be strong candidates as printing block material, they do not match the quality of Japanese yamazakura and the extremely high standards of professional ukiyo-e craft. The Japanese testing team found Finnish alder and birch to be closer to Japanese shina in their carving and printing properties, which was a positive evaluation. The research in Finland shows how innovative ideas in block manufacturing are still worth pursuing.

\section{The Future of Mountain Cherry in Japan}

In the pre-modern times, Japanese people went out to celebrate the spring and cherry blossoms on the mountains and riversides near villages. With the cultivation and propagation of someiyoshino and other decorative species of cherry during the Meiji-period (1868-1912) the custom of cherry blossom viewing begun to change. Nowadays, people prefer to gather in public parks and other designed scenic spots for admiring the impressive clouds of flowers instead of walking long distances to see the more modest yamazakura. The cultivated species have gradually started to mix with original mountain cherries and a pure strand of yamazakura is becoming ever more difficult to find in natural habitat. Agriculture and managed forestry have decreased the number of wild growing yamazakura trees as well. Genuine mountain cherry is difficult to identify when it is not flowering, so lumbermen often unintentionally cut them down like any other cherry timber.

Sixty percent of Japan's forests are natural forests while the rest $40 \%$ are planted forests. The major species for lumber production are sugi (cryptomeria or cedar), hinoki (cypress), and karamatsu (larch). Planting and protecting yamazakura, which is hard to harvest and needs a long time to grow before it can be utilized, is not on the priority list of forest owners.

Yamazakura, in its natural state, is best protected in Japan's many national parks and forests. National Forests comprise approximately $30 \%$ of the total forest area, or almost $20 \%$ of the total land area in Japan. Distributed in mountainous scenery with water source areas, the National Forests play vital roles in conservation of the natural environment. The most famous preservation area of various cherry species is Mt. Yoshino, located in Yoshino-Kumano National Park in Nara prefecture. 


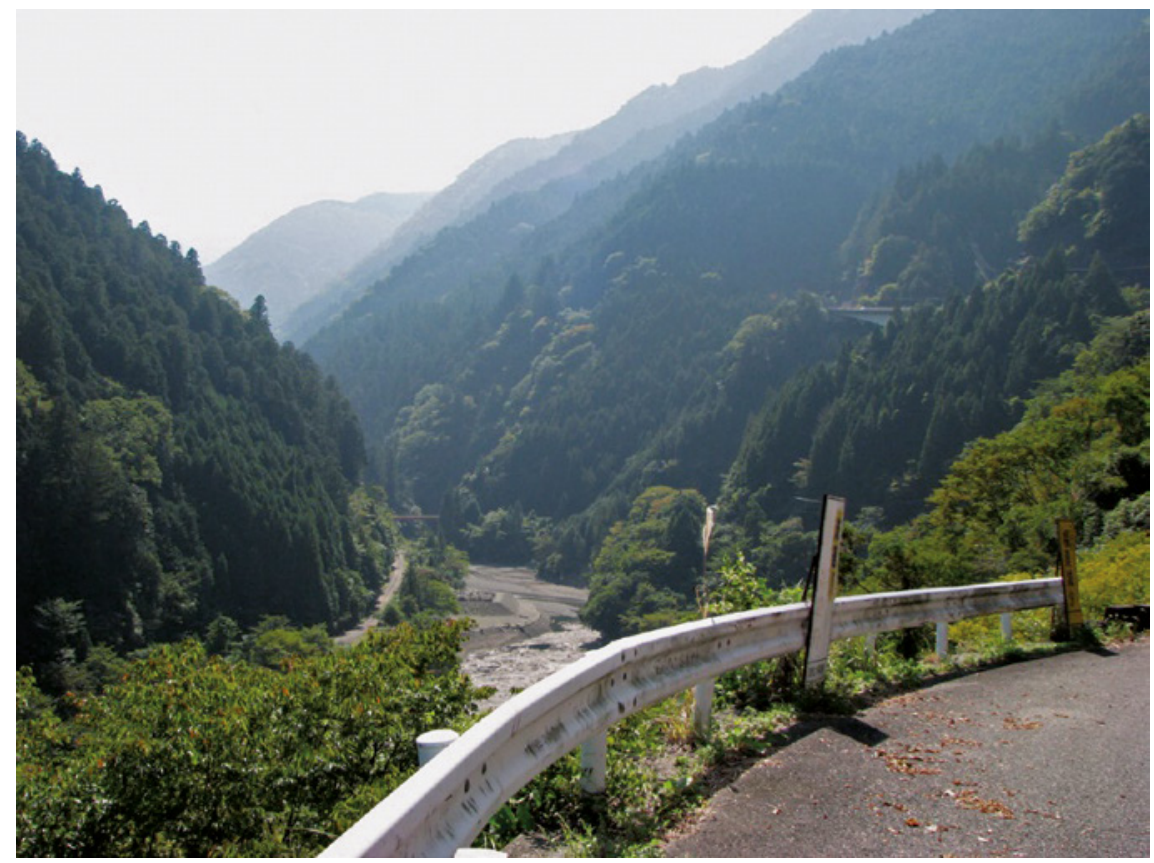

FIGURE 14 An old pilgrimage route passing through the Kii Mountains

Yoshino claims to contain around 200 different species of cherry and a total of 30 ooo cherry trees growing on its mountains. They are planted in different altitudes in order to lengthen the flower-viewing time in spring. During tourist season many of the trees are also lit up for the enjoyment of travelers. Yoshino is included in the UNESCo World Heritage sites as a part of an old pilgrimage route passing through the Kii Mountains (Fig. 14).

The future of Japanese traditional ukiyo-e craft is closely connected to the future availability of wild mountain cherries. Print production is continuing for the time being, thanks to the enthusiasm of devoted professional craftsmen and art lovers. Although the refined skills of carving and printing will eventually disappear under the flood of digital publishing, the beauty and strength of yamazakura wood will remain embedded silently in ukiyo-e prints for the times to come.

\section{References}

Arioka T. 2007a. Sakura I (Mono to Ningen no Bunkashi 137-I). Hōsei University Press, Tokyo, 有岡利幸: 桜I 、桜II。(ものと人間の文化史 137-1,137-11) 2007 年 法政大学 出版局. 
Arioka T. 2007b. Sakura II (Mono to ningen no Bunkashi 137-II) 2007, Hōsei University Press, Tokyo, 有岡利幸: 桜II (ものと人間の文化史 137-11) 2007年 法政大学出版局.

Hanga Geijutsu 124, Nihon no mokuhanga 100-nen. 2004. Dentōteki mokuhan no dōgu-zairyō no ima. 2004, Abe Publishing, Tokyo, 版画芸術124号、2004 年。日本の 木版画 100 年。伝統的木版の道具材料の今.

Ishii K. 1929. Nishiki-e no hori to suri. Unsōdō, Kyoto, 石井研堂: 錦絵の彫と摺。昭和 4 年、芸岖堂発行、京都.

Kaneko T. 2010a. Hanbon no hangi. Sono kihonteki kōzō (Physical Structure of Japanese Woodblocks for Printed Books). Art Documentation Kenkyu 17, 金子貴昭: 版本の版木 - その基本的構造。2010 年3月、アート・ドキュメンテーション学会、大阪.

Kaneko T. 2010b "Shōkiken Bokuchifuku" no hangi. Art Research Journal 10. Ritsumeikan University Kyoto, 金子貴昭:「賞奇軒墨竹譜」の版木。立命館大学、京都.

Kurosaki A. 2002. Hangashi Kaibō. 2002, Abe Publishing, Tokyo, 黒崎彰: 版画史解剖 阿部出版.

Makino T. 1982 Genshoku Makino shokubutsu daizukan (Makino's Illustrated Flora in Colour, p. 230-235). 1982, Hokkōkan, Tokyo, 牧野富太郎: 原色牧野植物大図鑑。昭 和 57 北降館、東京.

Miyoshi M. 1938. Sakura. 1938, Fuzanbō, Tokyo, 三好学: 桜。昭和13年 富山房、東京.

Mokuzai no kōgeiteki riyō. Nōmusho sanrin kyokuhen, Dainichi honzan rinkai. 1912, 「木材の工芸的利用」農務山林編、大日本山林会。大正元年.

Nihon no sakura no shurui. Hinshū manual. Nihon Hana no Kai publication 2007, Tokyo, 日本のサクラの種・品種マニュアル。2007年 日本花の会発行、東京.

Nihon Ukiyo-e Kyōkai, 1982. Genshoku Ukiyo-e Hyakka-jiten 3, page 84 Hori no dōgu / Hangi. Taishukan shoten, Tokyo, 日本浮世絵協会: 原色浮世絵大百科事典3 彫の道 具「版木」。大修館書店、東京.

Nishijima K. 1983 (1976). Hanga Nyūmon. Kiso, Jissaku, Ōyō. Bunken Shuppan, Tokyo, 西嶋勝之 : 版画入門。基礎、実作、応用。文献出版、東京.

Nodasaka S. 2011. Ki wo erabu. Zōenjumoku jiten. Apokkusha, Kamakura, 野田坂伸也: 木を選ぶ。造園樹木事典。2011年、アポックス社、鎌倉.

Tewaza ni manabu. Kyoto no dentōsangyō no genba kara. Learning from Handicraft: the sites of traditional Industries in Kyoto. 2008. Kyōto Seika University publication, 手技に学ぶ。京都の伝統産業の現場から。2008年、京都精華大学、学外実習 委員会.

Ukiyo-e Meisho Edo Hyakkei fukkoku monogatari. 2003. Tokyo Dentō Mokuhanga Kōgei Kyōkai publication, 浮世絵「名所江戸百景」復刻物語。平成 15 年、東京伝 統木版画工芸協会編.

Ukiyo-e Mokuhanga Chōshō Gijutsu Hozon Kyōkai Enkaku. Ukiyoe Mokuhanga Carvers and Printers Preservation Association: Outline of the history and development of the association and survey on current number of active members in 2010. 浮世絵木版画彫摺技術保存会、沿革、会員調査、平成 22 年、東京. 
Yoshida S. 1974. Ukiyo-e no kisochishiki. Yuzankaku shuppan, Tokyo, 吉田漱: 浮世絵の 基礎知識。雄山閣出版株式会社.

Yoshinoyama S. 1996. Taisaku Kentō-iinkai: Yoshino Yamazakura Kasseika chōsa hōkokusho. 1996, Nara-ken Nōrinbu research report, 吉野山「サクラ」対策検討委員 会: 吉野山サクラ活性化調査報告書。平成 7 年 3 月、奈良県農林部治山課発行.

\section{Interviews}

Keizō Satō, Master ukiyo-e printer, Satō Mokuhanga Kōbō, Kyoto (24 September 2014). Motoharu Asaka, Master ukiyo-e carver and printer, Tokyo (16 September 2014). Shigeru Matsumura, Block maker, WoodLike-Matsumura, Tokyo (15 September 2014). Watanabe Kenzai, lumberyard owner, Mr. Watanabe, Kyoto (23 September 2014).

\section{Collections Displaying Antique Printing Blocks and Prints}

Artbooks Yamazaki collection, Kyoto (26 September 2014).

Kumano Nachi Taisha hōmotsuten exhibition (1 October 2014).

Printing museum collection, Tokyo (15 September 2014).

\section{Internet Sources (January 2015)}

Annual Report on Forest and Forestry, Fiscal year 2013 (summary), Ministry of Agriculture, Forestry and Fisheries Japan, www.maff.go.jp/e/.

Eco Net Tokyo, Eco Academy no19, http://all62.jp/ecoacademy/19/o1.html.

Gōhan Plywoods, www.gouhan.net/plywood-sina-tomo.htm.

Hirakawa Mokuzai Kōugyō, www.hirakawa-mokuzai.co.jp/column/timber/wood character.

Mokuzai Hakubutsukan, www.wood-museum.net/yamazakura.php.

Mt. Yoshino Tourist Association, www.yoshinoyama-sakura.jp/english/flowers.htm.

Seo Mokuzai, Tokyo, http://seomokuzai.blogdehp.ne.jp/category/1312599.html.

Shinshū Kurohime Tokkoyasan, www.tokkoyasan.com/sakura.htm.

Yoshino Sakura Hōshōkai, http://www.hoshoukai.yoshino.jp/bring_1.htm.

Zaimokuya Zaiichi, Kyoto, www.zaiichi.com/gouhan/gouhan.html. 